Relations industrielles

Industrial Relations

\title{
Craig HERON, Robert STOREY : On the Job : Confronting the Labour Process in Canada. Kingston and Montréal, McGill-Queen's University Press, 1986, 360 pp., ISBN 0-7735-0598-9
}

\section{Robert H. Zieger}

Volume 42, numéro 1, 1987

URI : https://id.erudit.org/iderudit/050296ar

DOI : https://doi.org/10.7202/050296ar

Aller au sommaire du numéro

\section{Éditeur(s)}

Département des relations industrielles de l'Université Laval

ISSN

0034-379X (imprimé)

1703-8138 (numérique)

Découvrir la revue

Citer ce compte rendu

Zieger, R. H. (1987). Compte rendu de [Craig HERON, Robert STOREY : On the Job : Confronting the Labour Process in Canada. Kingston and Montréal, McGill-Queen's University Press, 1986, 360 pp., ISBN 0-7735-0598-9]. Relations industrielles / Industrial Relations, 42(1), 216-218.

https://doi.org/10.7202/050296ar

Tous droits réservés (C) Département des relations industrielles de l'Université Laval, 1987
Ce document est protégé par la loi sur le droit d'auteur. L'utilisation des services d'Érudit (y compris la reproduction) est assujettie à sa politique d'utilisation que vous pouvez consulter en ligne.

https://apropos.erudit.org/fr/usagers/politique-dutilisation/ 
tente de reproduire le texte de la loi presqu'intégralement. Les auteurs renvoient aussi aux autres dispositions légales rattachées à l'article discuté ainsi qu'aux règlements pertinents.

Cette démarche explique l'accent mis sur les chapitres consacrés à des matières plus juridiques telles le droit de refuser d'exécuter un travail dangereux, le retrait préventif de la femme enceinte ou qui allaite, l'inspection, les bureaux de révision, les recours à l'encontre de mesures disciplinaires ou discriminatoires et les infractions: la jurisprudence rendue jusqu'à maintenant porte essentiellement sur ces différents aspects. Les auteurs ont trouvé là matière à discussion et le lecteur est bien servi. Ces sections ou chapitres recèlent des informations précieuses, aussi bien pour le praticien en droit que pour l'administrateur. Les auteurs renvoient souvent à des décisions juridiciaires non publiées. Ces renvois sont utiles mais soulèvent le problème de l'accès à ces données et aussi celui de la sélection et partant, de la fiabilité de l'information: les auteurs ont-ils été vraiment exhaustifs ou ont-ils plutôt référé aux décisions rencontrées çà et là au gré de leur pratique professionnelle?

Par ailleurs, les lecteurs s'intéressant davantage aux institutions en matière de santé et de sécurité sont laissés pour compte. En ce qui concerne des sujets comme le comité de santé et de sécurité, le représentant à la prévention, la santé au travail, les associations sectorielles ou encore les programmes de santé et de prévention, les auteurs se limitent à paraphraser le texte de la loi et à référer, lorsque nécessaire, aux dispositions réglementaires pertinentes. On peut alors présumer que la jurisprudence est pauvre, sinon inexistante, sur le sujet - ce qui n'est pas toujours inutile. Néanmoins, plusieurs praticiens nécessitent une information allant au-delà de celle contenue dans les textes légaux et réglementaires. Ce n'est pas cet ouvrage qui la leur fournira.

En conclusion, les auteurs nous proposent un outil honnête, bien fait et utile. Tous ceux que le droit de la santé et de la sécurité au Québec intéresse voudront le consulter. L'outil rencontre, par contre, les limites que sa nature lui impose. Dans ce sens, il reste encore beaucoup de place à la recherche future dans ce domaine.

Gilles TRUDEAU

École de relations industrielles

Université de Montréal

On the Job: Confronting the Labour Process in Canada, Ed. by Craig Heron and Robert Storey, Kingston and Montréal, McGill-Queen's University Press, 1986, xiv +360 pp., ISBN 0-7735-0598-9 (cloth) and ISBN 0-7735-0599-7 (paper)

The themes of workers' control and the labour process have been among the most prominent with labour historians in the U.S. and Canada over the past decade. This volume makes a significant contribution to the literature. Each of the twelve individual essays is original to this book. In addition to a broad introductory piece by the editors, the volume contains eleven contributions by youngish scholars, reporting on work relating to dissertations and similar recent projects. All of the contributions are fluent, abreast of the literature, and, at least implicitly, politically engaged. While a broad Marxist orientation is not acknowledged in all cases, the dominant conceptual mode derives from neo-Marxist perspectives. All of the essays exhibit deep sympathy with working people, animosity toward business and capitalism, and disappointment with the limitations of trade unionism. None of the authors seems to be impressed with the material standards or the degree of social and political freedom that workers have attained over the past $\mathbf{1 5 0}$ years. Indeed, the overall picture of the fate of working people focuses on victimization and subordination. Several essays, notably Ester Reiter's on fast food workers and Don Wells' on automobile workers, seem despairing. 
The editors' introduction holds out the prospect that the volume will move beyond the frame of reference that David Montgomery (Workers' Control in America, 1980) and Harry Braverman (Labor and Monopoly Capital, 1974) have established. And indeed Heron and Storey, while endorsing the basic perspective of these Marxist historians, do argue that the simple model of deskilling often associated with them is inadequate. Capitalism's relentless drive for profit and control, they acknowledge, has often involved «reskilling», as new processes call for new aptitudes and training. Thus, they offer at least a partial way out of the dilemma facing historians who stress the unilinear degradation of work, namely accounting for the willingness of broad sectors of the working class to tolerate and even embrace a system depicted as ruthless and dehumanizing. If in fact the system permits genuine possibilities of job satisfaction while delivering high material standards and impressive social and political freedom (at least in comparison with other extant systems), no wonder it has proven so durable.

Heron and Storey do not carry the theme of reskilling this far. Its impact, in their view, is limited and short-term, lending plausibility rather than legitimacy to the system. Some of the individual essays, notably Graham S. Lowe's informative piece on 20th century office work, follow through on the reskilling theme, adding a note of complexity to a literature that often reads like an academic version of Modern Times.

Most of the essays, however, are little concerned with the system's enduring economic and political success, nor do most offer extended discussions of the reskilling theme. Whether the subject is Wells' autoworkers, Reiter's hamburger pushers, or Mercedes Steedman's clothing workers, the twentieth century work experience has offered little to Canadian except deskilling, intensification of work, and alienation. Unions are either impossible (among teenaged fastfood employees) or ineffectual, as among clothing and autoworkers. Aside from some oblique remarks in the introduction, it is only Don Wells in the book's concluding piece who explicitly identifies the ideological and indeed moral basis of the critique running through the collection generally. Citing intensified production schedules, ever harsher assembly-line discipline, and union enfeeblement over the past generation, Wells writes:

As we enter the tenth year of the most profound structural crisis of world capitalism since the depression of the 1930s, as Pax Americana retreats before a new world division of labour, even greater restraints have been placed on the flxibility of labour/management relations in the old Western metropolitan core of world capitalism. A crux of the matter is this: the previous limits of worker resistance, both institutionalized and informal, are no longer tolerable... Continued successful capital accumulation requires massive new investment... As a consequence, the crisis precludes the kind of buying off of discontent that workers experienced in the post-war boom... Employers in many sectors will no longer be able to buy off workers with summer cottages and expensive cars. (346-47)

These remarks, along with the editors' introduction and the implicit critique of capitalist political economy running through the essays, reveal the books' central, if not always acknowledged, perspective.

Each of these essays is informative and the collection as a whole exhibits the strengths of recent historical scholarship as it pertains to work. Detailed studies by Ian Radforth and John Bellamy Foster on pulpwood loggers and longshoremen, respectively, are models of careful investigation of work processes, economic and technological change, and the strengths and limitations of unions. Pieces by Gregory Kealey and Paul Craven and Tom Traves on printers and railwaymen in the 19th and early 20th centuries exploit new sources to bring fresh perspective to familiar subjects. David Frank's discussion of Cape Breton coal miners in the 1920s 
stresses the relationship between workplace control and political and social power in another familiar context. Frank, however, fails to factor in economic constraints on Canadian soft coal production in the 1920s in his optimistic assessment of the case for worker ownership. Veronica Strong-Boag's contribution usefully puts housework on the labour history agenda, though its strength lies more in suggesting categories of analysis than in adding to our knowledge of housewives' work. Heron and Storey combine more traditional union history with an authoritative survey of technological change in steelmaking, stressing the limited nature of the union's victory in the World War II period.

There is no separate contribution on government employment, though Lowe does suggest the primacy of civil service demands for efficiency in establishing new office procedures and technologies in the economy generally. The essays are not so much silent as ambivalent on the question of whether control of workers, deskilling, and the degradation of work owe primarily to the quest for profit or the impulse to impose and maintain subordination. Capitalists and managers remain shadowy, seemingly as much the objects of impersonal forces of profitseeking and capital accumulation as the oppressed and alienated workers who toil under them. Protest, while inspring and reflective of workers' inextinguishable (til now, anyway) spunk, seems futile and even self-defeating, given capitalism's political and instutional strength.

Readers without the authors' political and ideological agenda will nonetheless learn from On the Job. Some of the contributions (Lowe's, Radforth's, and Reiter's stand out) offer detailed descriptions of work processes and workers' responses. Others, notably Wells' rather polemical piece on autoworkers, are less illuminating. The contributors' unwillingness to put their work into the context of the overall funtioning of the economic system and their lack of responsiveness to the continuing appeal of that system among their subjects should not discourage a wide readership. In both its strengths and weaknesses, this book serves as a good interim report on the state of the art of historical writing relating to work and labour processes.

Robert H. ZIEGER

University of Florida

Compensation, par George T. Milkovich et Jerry M. Newman, Plano, Texas, Business Publications Inc., 1984, 549 pp., ISBN 0-256-02204-6

Compensation est un livre qui, comme son titre l'indique, est consacré à la rémunération.

Les auteurs, conscients de la complexité des décisions portant sur la détermination de la rémunération des membres d'une organisation, ont voulu écrire un ouvrage qui ne soit pas un simple livre de recettes sur la rétribution des travailleurs, mais qui présente plutôt les multiples facettes à considérer dans la prise de décision en cette matière.

Principalement axé sur le concept ou la théorie dite de l'équité en matière de rémunération, l'ouvrage comprend cinq (5) sections. Les trois premières portent respectivement sur l'équité interne des structures de salaires, sur l'équité externe, ainsi que sur ce que les auteurs appellent, l'équité aux yeux des travailleurs. Les deux autres sections qui complètent l'ouvrage traitent des avantages sociaux et de la gestion des systèmes de rémunération.

Dans la première section intitulée «Internal Equity: Determining the Structure», les auteurs, après avoir défini ce qu'ils entendent par l'équité interne, présentent ensuite les différentes techniques susceptibles d'atteindre cette équité: analyse des tâches et évaluation des emplois. Puis, cette section est complétée par un chapitre qui porte sur les aspects légaux de l'application du «Equal Pay Act» aux U.S.A. 